\title{
Spray Fire Tests with Hydraulic Fluids
}

\author{
GÖRAN HOLMSTEDT
}

Department of Physics, Lund Institute of Technology

P.O. Box 118, S-221 00 Lund, Sweden

\section{HENRY PERSSON}

Division of Fire Technology, National Testing Institute

P.O. Box 857, S-501 15 Borås, Sweden

\section{ABSTRACT}

Two test series simulating the hazards associated with the accidental release of hydraulic fluid near to a source of ignition have been carried out with six hydraulic fluids; mineral oil, organie ester, phosphate ester, water in oll emulsion and two polyglycols in water solution.

In one of the test series the fluids were sprayed $\left(1-4 \mathrm{~kg}^{\left.\mathrm{min}^{-1}\right)}\right.$ through different nozzles at various hydraulio pressures into a diffusion flame under a semi-open hood which collected all the combustion gases; thus the rates of generation of smoke and gases $\left(\mathrm{O}_{2}, \mathrm{CO}, \mathrm{CO}_{2}\right)$ could readily be measured.

In the other test series the fluids were sprayed $\left(7-30 \mathrm{~kg} \mathrm{~min}^{-1}\right)$ through various nozzles at various hydraulic pressures into a diffusion flame or against a hot metal plate in a large fire hall. The flame length, temperature and radiation and the auto-ignition temperature were measured.

The correlation between the two test series regarding rates of heat release between 1 and $20 \mathrm{MW}$ was very good. As a result a test method is proposed. In this test method the flammability hazard of hydraulic fluid spray fires is measured in terms of their combustion efficiency, net heat of combustion, radiant fraction and smoke and toxic rate of production.

Keywords: Hydraulic fluids, Spray combustion, combustion efficiency, Smoke, Toxic gases, Auto-ignition temperature, RHR-measurements.

\section{INTRODUCTION}

Hydraulic fluids have been the subject of concern due to the fire hazards associated with them especially in industries where "hot processes" are used, such as steel-making plants, steel-rolling mills, forge workshops etc. In Sweden, for example, a number of fires have been caused by leaking hydraulic fluid which has led to very expensive damage [1].

The most common source of leakage in hydraulic systems is from fittings, valves, steel reinforced rubber hoses and steel and copper pipes. The high pressure in the hydraulic system leads to leakage in the form of very fine sprays. Hydraulic fluids which, 
When held in bulk are not particularly flamable, can therefore through leakage, in the form of fine sprays, atmoize and apon ignition lead to very large flames.

The risk of hydraulic fluid fires can be minimized in many ways; engineering, through the introduction of warning and fluid-stop systems, hose break valves, dolble pipes, sprinklers eto., and chemicaliy, by changing the composition nature of the hydraulic fluid. A fluid spray's tendency to combust is influenced by many factors such as aroplet size distribution, the fluid's flash-point, auto-ignition temperature, heat of combustion etc. The droplet size can increase, for example, through the addition of certain polymers, which have high molecular weights. These polymers, which reduce the tendency to formation of mists, are on the other hand very sensitive to shear forces and degrade quickly in the hydraulic system due to the wear caused by the moving parts of pumps, filters and valves [2].

A number of hydraulic fluids, which have a higher flash-point and auto-ignition temperature and a lower heat of combustion than mineral oil, have been developed and are normally called "fireresistant hydraulic fluids". These include oil in water emulsions, water in oil emulsions, polyglycols in water solutions, phosphate esters, halogenated hydrocarbons and organio esters. It is then necessary to introduce modifications into the hydraulic system for many of these fluids, in order to make seals and metals compatible with the fluid. The problem of toxic substances can also arise with the fluids and their combustion products; this is especially the case with fluids containing phosphates and halogenated hydrocarbons.

The concept "fire-resistant hydraulic fluids" is a diffuse concept which relates to manufacturers' or institutions' classification rules based on small-scale tests [2-12]. The tests, whioh are normally carried out with a limited quantity of fluid $(0.05-0.5 \mathrm{~kg}$ min $\left.{ }^{-1}\right)$, very often give no quantitative information about any combustion property. Instead the fluid is "passed" or "falled". Fluids which, according to such tests have been classified as fire-resistent, however, have caused severe damage in industrial environments and have under other tests $[11,13]$ given results which indicate that the difference between their combustion properties and the combustion properties of mineral oil is not so large.

Two test series have been carried out with six hydraulio fluids. In these tests the combustion efficienoy, radiant fraction, water content, auto-ignition temperature and rate of production of smoke and toxic gases were determined.

\section{EXPERIMENTAL METHOD}

Test equipment

Two sets of test equipment have been used. In one of the test series the hydraulic fluid was sprayed (1-4 kg min $\left.{ }^{-1}\right)$ through different nozzles at various hydraulic pressures into a diffusion flame under a semi-open hood which collected all the combustion gases, Fig. 1. The hood was connected to an evacuation system through an exhaust duct and equipped with shields to collect the combustion gases. The openings on both sides of the spray were in total $10 \mathrm{~m}^{2}$ and the entrance opening of the hood $9 \mathrm{~m}^{2}$. During the 


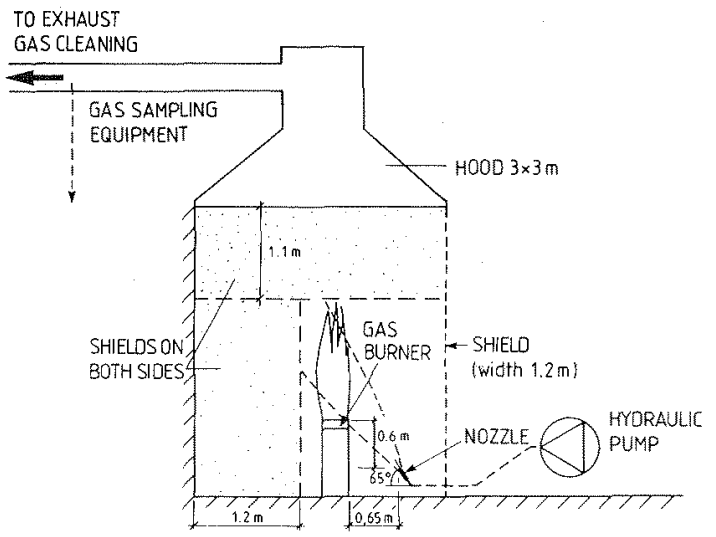

Fig. 1 Experimental equipment $\left(1-4 \mathrm{~kg} \mathrm{~min}^{-1}\right)$
a) semi-open hood
b) analytical equipment

test air was evacuated at a rate of approximately $4 \mathrm{Nm}^{3} \mathrm{~s}^{-1}$, giving an average speed of the cold gas so low $\left(<0.5 \mathrm{~ms}^{-1}\right)$ that it did not interfere with the spray flame. In the exhaust duct, where the gases were well mixed, mass flow (pilot tube, thermocouple, velocity profile), optical smoke density and gas composition $\left(\mathrm{O}_{2}, \mathrm{CO}\right.$, $\mathrm{CO}_{2}$ ) were measured as shown in $\mathrm{Fig}$. 1. The test equipment is presented in more detail in ref. 14 .

In the other test series the fluids were sprayed $\left(7-30 \mathrm{~kg} \mathrm{~min}^{-1}\right)$ through different nozzles at various hydraulic pressures through a diffusion flame or against a not metal plate in a large fire hall $(18 \times 22 \times 20 \mathrm{~m})$, Fig. 2. The flame length, temperature and radiation were measured.

\section{Fluid spray}

The fluid flow to the spray nozzle was provided by a hydraulic pump. The pressure in the system could be adjusted between 0 and 30 MPa using a pressure limiting valve, and the temperature between 10 and $90{ }^{\circ} \mathrm{C}$ using a thermostatically controlled electrical heater mounted on a 1601 hydraulio reservoir. The hydraulio pressure in the nozzle was measured using a pressure transducer of strain gauge SIDE VIEW

FRONT VIEW

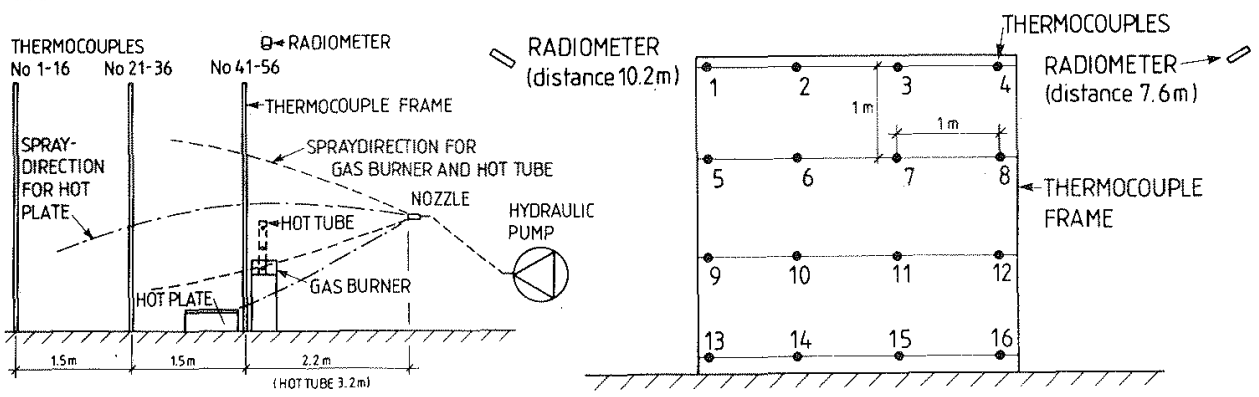

Fig.2 Experimental equipment in a large fire hall (7-30 kg min $\left.{ }^{-1}\right)$. 
type ( 34.5 MPa, $0.25 \%$ accuracy, 0.1 ms time constant), the temperature using a thermocouple and the fluid flow using a turbine wheel gauge (30 I $\mathrm{min}^{-1}$, $1 \%$ accuracy, 1 s time constant). The flowmeter was calibrated for the different fluids at the working temperature by measuring the amount of fluid which flowed through it in a 8 iven time.

To simulate real leakages which can give rise to many different types of sprays, four different hydraulio pressures and four different nozzles were used. In this way the number density and size distribution of the drops could be varied in order to avoid that the results being be too dependent on a single spray form. Information about the nozzles used, ( manufactured by spraying Systems Co.) which give homogeneous sprays is given in Table 1.

Table 1: Data regarding the nozzles

\begin{tabular}{|c|c|c|c|c|c|}
\hline test equipment & nozzle & coneangle, deg. & hydraulic pressure, $\mathrm{MPa}$ & fluid flow, $1 \mathrm{~min}^{-1}$ & med.vol. diam, $\mu \mathrm{m}\left(\mathrm{H}_{2} \mathrm{O}, 21^{\circ} \mathrm{C}\right)$ \\
\hline semi-open hood & Tg 0.7 & 60 & $5,10,15,25$ & $2-4$ & $130-90$ \\
\hline lange fire hall & $\mathrm{D} 5 / 56$ & 30 & 15,25 & $23-27$ & $200-150$ \\
\hline
\end{tabular}

\section{Ignition sources}

The sprays were ignited by a diffusion flame from a porous propane burner $(0.3 \times 0.3 \mathrm{~m})$ with a power of $200 \mathrm{~kW}$. In addition a hot steel plate was used as the ignition source in some tests in the large fire-hall. The plate $(0.65 \times 0.75 \times 0.02 \mathrm{~m})$ was heated from below with a thermostatically controlled electrical heater. Due to radiation losses the steel plate was insulated during the heating period. Just before the test the insulation was withdrawn whereupon the surface temperature slowly started to decrease. During a test the surface temperature, as indicated by three thermocouples fell by less than $25^{\circ} \mathrm{C}$.

\section{Hydraulic fluids}

The results of the tests were used to compare the combustion properties of the different hydraulic fluids with the combustion properties of mineral oil. To complement the manufacturers' data, the water content and the heat of combustion were determined and are given together with other values in Table 2 .

Table 2. Tested hydraulic fluids

min.oil org.ester phosph.ester water in oill em. pol.glyc.I in w.s. pol.glyc.II in w.s.

\begin{tabular}{|c|c|c|c|c|c|c|c|}
\hline density, $\mathrm{kgm}^{-3}$ & + & 892 & 920 & 1125 & 964 & 1055 & 1064 \\
\hline visoosity, cst $\left(40^{\circ} \mathrm{C}\right)$ & + & 66.8 & 40.0 & 43.0 & $110\left(38^{\circ} \mathrm{C}\right)$ & $43\left(38^{\circ} \mathrm{C}\right)$ & 45 \\
\hline flash-point, ${ }^{\circ} \mathrm{C}$ & + & 212 & $280^{\circ}$ & 245 & data missing & - & - \\
\hline auto-ign. terlp. ${ }^{\circ} \mathrm{C}$ & + & 350 & 460 & 545 & data missing & - & - \\
\hline water cont., of of weight. & & 0 & 0 & 0 & 38 & 35 & 35.2 \\
\hline heat of camb. , $\mathrm{kJg}_{-1}^{-1}\left(\mathrm{H}_{2} \mathrm{O}\right.$ & liq.) & 45.0 & 39.8 & 32.4 & 29.2 & 16.9 & 14.6 \\
\hline heat of $a m b ., \mathrm{kJg}^{-1}\left(\mathrm{H}_{2}^{2} \mathrm{O}\right.$ & gas & 42.3 & 37.7 & 30.3 & 26.6 & 14.7 & 12.5 \\
\hline
\end{tabular}

+ manufacturess data 


\section{Test procedure}

The temperature of the hyoraulic fluid was kept constant at $37 \pm 2$ ${ }^{\circ}$. The pressure was adjusted to the desired value and the fluid was allowed to oirculate back to the reservoir. For the experiments under the semi-open hood the ignition source was allowed to burn for 30 s before the spray was turned on by shifting the fluid flow from recirculating to the spray nozzle with an electrically controlled three-way valve. The spray was allowed to burn for another $30 \mathrm{~s}$ with the ignition source on. For the experiments in the large fire-hall the corresponding times were 5 and 20 s. The experiments were repeated using different pressures, nozzles, hydraulic fluids and ignition sources. In all about 150 tests were carried out.

\section{CALCULATIONS}

Rate of heat release and combustion efficiency

In the experiments under the semi-open hood the rate of oxygen consumption was measured. This is a way of estimating the rate of heat release as the heat of combustion per unit of oxygen consumed is approximately the same for most fuels [15]. The rate of heat release, $q$, is given by [16]:

$\mathrm{q}=17.2\left(\mathrm{X}_{\mathrm{O}}^{\mathrm{O}}-\mathrm{X}_{\mathrm{O}}^{\mathrm{s}}\right) \dot{\mathrm{V}}_{\mathrm{S}} / \alpha$

$q=$ rate of heat release, $M W$

where

$x_{02}^{\circ}=$ volume of oxygen in the incoming air

$\mathrm{X}^{\mathrm{S}} \mathrm{O2}=$ volume $\%$ of oxygen in the exhaust gases

$\dot{V}_{\mathrm{s}} \mathrm{O}=$ volume flow of the exhaust gases, $\mathrm{m}^{3} \mathrm{~s}-1$ ( $\left.25^{\circ} \mathrm{C}, 0.1 \mathrm{MPa}\right)$.

$\alpha=$ expansion factor for the fraction of air that is depleted of its oxygen $(\approx 1.1)$

The total inaccuracy, including the factors which have been neglected in the formula above ( $\mathrm{CO}$ and $\mathrm{H}_{2} \mathrm{O}$ content) is estimated to be $25 \mathrm{~kW}$ or $\pm 10 \%$ of the calculated value. Starting from the calculated rate of heat release the combustion efficiency can be derived from:

$\emptyset=\left(q-q_{i q n}\right) /(\dot{m} \cdot Q)$

where

$\emptyset=$ combustion efficiency

${ }^{\mathrm{q}}$ ign $=$ power of the ignition source $=0.2 \mathrm{MW}$

$Q=$ heat of combustion of the hydraulio fluid, $\mathrm{MJ} \mathrm{kg}^{-1}$ ( $\mathrm{H}_{2} \mathrm{O} \mathrm{gas}$ )

\section{Production of smoke and toxic gases}

In the experiments under the semi-open hood the volume flow, Iight obstruction, and the $\mathrm{CO}-$ and $\mathrm{CO}_{2}$ concentrations in the exhaust gases were measured. The smoke potential is given by [17]:

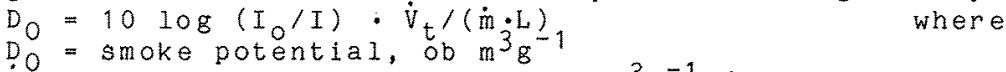

$\dot{V}_{t}^{0}=$ volume flow exhaust gases, $m^{3} s^{-1}$ (at exh. gastemp. and press).

$m^{t}=$ mass flow of the hydraulio fluid, $\mathrm{gs}^{-1}$

$\mathrm{L}=$ diameter of the exhaust duct, $m$

In a similar manner the $\mathrm{CO}-$ and $\mathrm{CO}_{2}$ potential, $1 \mathrm{~g}^{-1}$, can be calculated. The total inaccuracy is estimated to be $\pm 10 \%$ of the calculated value. 
The radiation was measured using two Medtherm radiometers (10 $\mathrm{kWm}^{-2}$, 3\% accuracy) placed at different distances on either side of the flame axis. It is difficult to calculate the total radiated power from only two point measurements. The flames from nozzles Tg 0.4 , Tg 0.7 and D3/31, however, were approximately spherical and small compared with the distance, $r$, to the radiometers, so that the power could be estimated by the measured radiation multiplied by $4 \pi r^{2}$. The flames from nozzle $D 5 / 56$ were comparable in length to the distance to the radiometers. In this case the total radiation was calculated by regarding the flame as a cylinder which radiated with uniform intensity and with a length equal to the flame length. The difference in calculated power from the two radiometers was less than $10 \%$.

\section{RESULTS}

Rate of heat release and combustion efficiency

Tests were carried out under the semi-open hood with six hydraulic fluids at four pressures using two different nozzles. The rate of heat release and the generated heat per gram sprayed organio ester as a function of time are shown in Figs. $3 a$ and b, respectively. When the ignition source is on the rate of heat release stabilizes at $0.2 \mathrm{MW}$. Thirty seconds later when the spray is applied the rate of heat release increases and stabilizes at a new level. The generated heat per gram fluid, and consequently the combustion

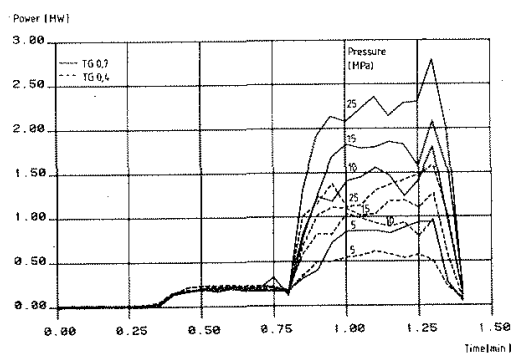

Fig. 3 a) RHR for organic ester as a function of time.

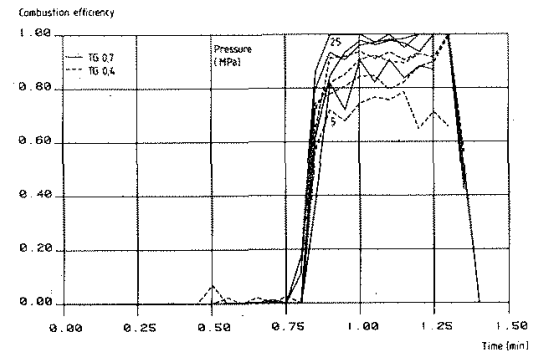

Fig. 4 a) Combustion eff. for min.oil as a function of time.

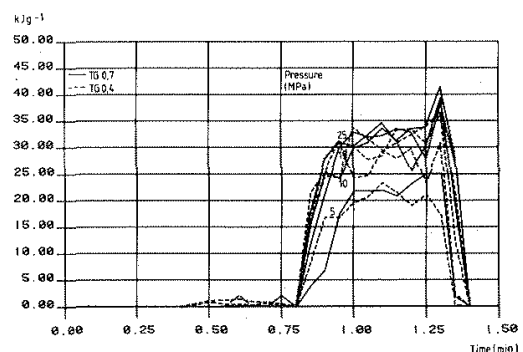

b) Generated heat per gram sprayed org.ester as a function of time. tombustion elficiancy

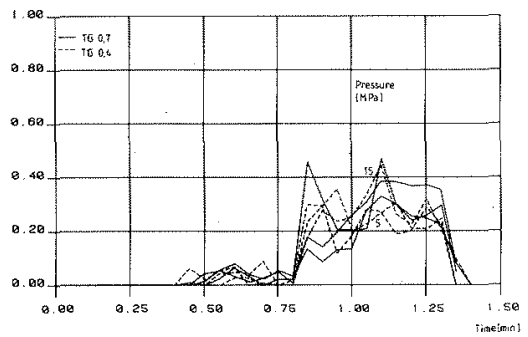

b) Combustion eff. for polyglycols I in water solution as a function of time. 
efficiency, is, as shown in Figs. 3b, $4 a$ and $4 \mathrm{~b}$, relatively independent of the hydraulio pressure and the nozzle used. The results are given in more detail in ref. 18 . In Table 3 the combustion efficiencies are given for the hydraulic fluids tested.

Production of smoke and toxic gases

The smoke-, $\mathrm{CO}^{-}$and $\mathrm{CO}_{2}$ potential were also found to be relatively independent of the hydraulic pressure and nozzle used. In Figs. 5a and $b$ the $\mathrm{CO}$ - and $\mathrm{CO}_{2}$ potential are shown as a function of time and in Table 3 the potentials for the tested hydraulic fluids are given.

Table 3 . Test results

min.oil org.ester phosph.ester water in oil em. pol.glyc.I in w.s. pol.glyc.II in w.s.

\begin{tabular}{lllllll}
\hline combust.efficiency, & 90 & 00 & 70 & 60 & 30 \\
radiant fraction, 8 & 32 & 20 & 32 & 20 & 10 & 0.1 \\
smoke potential, $\mathrm{com}^{3} \mathrm{~g}^{-1}$ & 0.2 & 0.2 & $2-6$ & 0.4 & 0.1 & 0.02 \\
o pot. $1 \mathrm{~g}^{-1}\left(25^{\circ} \mathrm{C}, 0.1 \mathrm{MPa}\right)$ & 0.03 & 0.035 & 0.1 & 0.035 & 0.2 \\
o $_{2}$ pot. $1 \mathrm{~g}^{-1}\left(25^{\circ} \mathrm{C}, 0.1 \mathrm{MPa}\right)$ & 1.7 & 1.3 & 0.8 & 0.6 & 0.2 \\
\hline
\end{tabular}

\section{Radiant fraction}

It was also found that the radiant fraction was relatively independent of the hydraulic pressure and the nozzle used. In Figs. $6 \mathrm{a}$ and $\mathrm{b}$ the measured radiation level and the radiation energy per gram sprayed fluid are shown. In Table 3 the radiant fraction is given for the fluids tested.
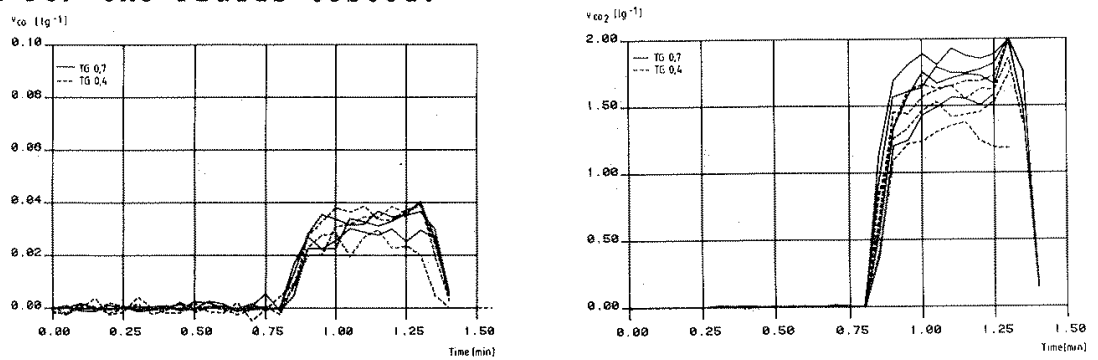

Fig.5 a)CO-potential for w.i.oil emulsion b) $\mathrm{CO}_{2}$-potential for mineral oil as a function of time.

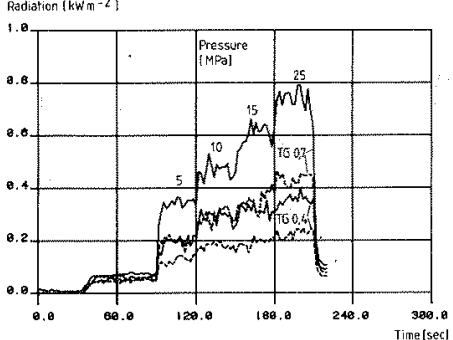
as a function of time.

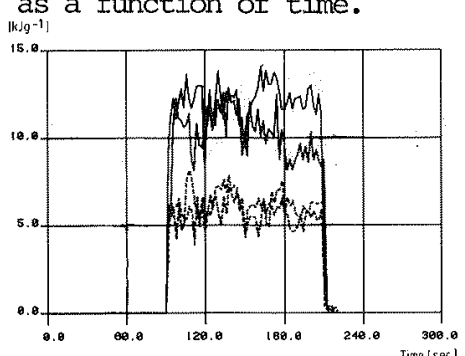

Fig. 6 a) Radiation level from flames of min.oil (-) and org.ester (- -) as a function of time.

b) Radiation per gram fluid as a function of time(Fig 6a divided by the mass flow). 
The length of the flames in the tests carried out in the large fire-hall was estimated from pictures and video recordings. The geometry of the flames were somewhat different depending on whether the fluid was sprayed freely in the air, which was the case with a diffusion flame as the ignition source, or if the fluid was sprayed close to the floor which was the case with the hot plate. In Figs. 7 a and b some typical pictures are shown from comparable tests with the diffusion flame. In Fig. 70 comparable tests are shown with the hot plate. In the tests using the hot plate, the mineral oil and organic ester started a heavy pool fire in the fluid which hit the floor. The pool fire stabilized the flames which increased in intensity and gave rise to a strong turbulence rumble and a heavy smoke generation. Under the same test conditions phosphate ester and water-in-oil emulsion only gave rise to a small pool fire on the floor and the two polyglycols in water solution produced only a small local fire at the ignition source.

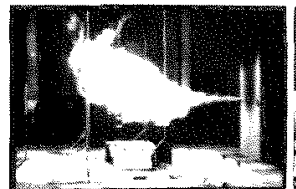

Mineral oil $2 \mathrm{~m}$

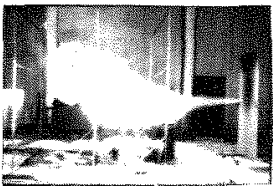

Organic ester $2 \mathrm{~m}$

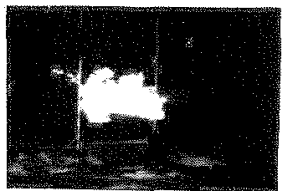

Water in oil emulsion

$1.5 \mathrm{~m}$

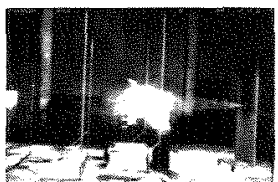

Polyglycols in water solution $0.75 \mathrm{~m}$

Fig. 7 a) Flame lengths from free sprays with nozzle D3/31 ( $7 \mathrm{~kg} \mathrm{~min}$ ) at $15 \mathrm{MPa}: \mathrm{s}$ pressure.

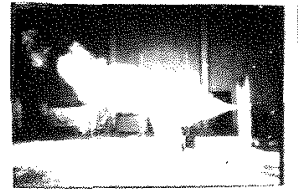

Mineral oil $5.5 \mathrm{~m}$

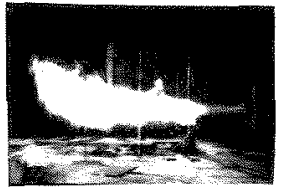

Organic ester $5 \mathrm{~m}$

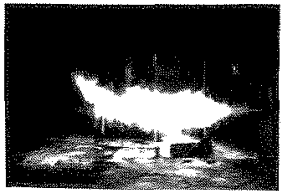

Water in oil emulsion $3.5 \mathrm{~m}$

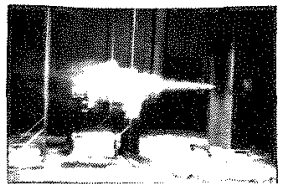

Polyglycols in water solution $1.25 \mathrm{~m}$

b) Flame length from free sprays with nozzle D $5 / 56$ $\left(23 \mathrm{~kg} \mathrm{~min}{ }^{-1}\right)$ at $15 \mathrm{MPa}: \mathrm{s}$ pressure.

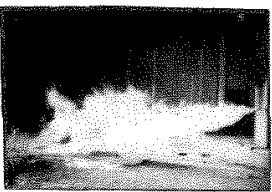

Mineral oil

$7 \mathrm{~m}$

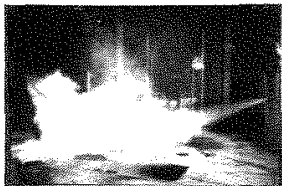

Organic ester $5 \mathrm{~m}$

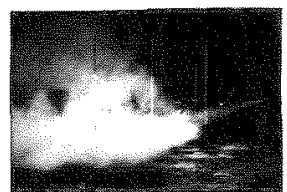

Water in oil emulsion $3 \mathrm{~m}$

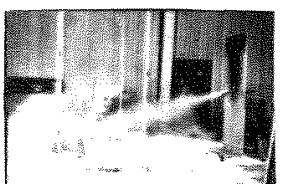

Polyglycols in water solution $0 \mathrm{~m}$

c) Flame lengths from, sprays close to the floor with nozzle D5/56 (23 $\left.\mathrm{kg} \mathrm{min}^{-1}\right)$ at $15 \mathrm{MPa}: \mathrm{s}$ pressure. 
The auto-ignition temperature of the fiuids was determined by testing the fluid sprays against a hot surface at various temperatures. In Table 4 the highest surface temperature at which ignition did not occurred and the lowest temperature at which ignition did occur are shown together with the auto-ignition temperature given by the manufacturers. The results are in good agreement since a difference of 50 to $100^{\circ} \mathrm{C}$ between different test methods is not unusual [19].

Table 4. Automignition temperature

mineral oil onganic ester phosphate ester water in oil en. pol.glyo.I in w.s. pol.glyc.II in w.s.

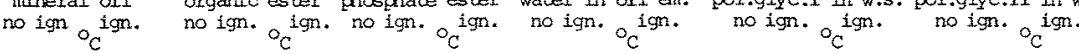

\begin{tabular}{|c|c|c|c|c|c|c|c|c|c|c|}
\hline manuf. data & 300 & 350 & 400 & 450 & 500 & 550 & \multicolumn{2}{|c|}{$\begin{array}{l}350 \\
\text { misssing }\end{array} 40$} & & $>900$ \\
\hline
\end{tabular}

\section{DISCUSSION}

The risks of injury on personnel and damage to property which arise from hydraulic fluid fires are caused by spray flames, secondary fires and the presence of smoke and toxic gases. Flame length, rate of heat release, radiation and the generation of smoke and toxic gases are the most important factors which it is necessary to determine to be able to assess the hazards.

The flame length is dependent on the extent of the leakage as well as on the combustion properties of the fluid. In the aerosol the droplets are not uniformly distributed with respect to size and number. The smaller droplets are easily retarded and cause the spray to mix with the surrounding air [20]. If the droplets combustion time is short the flame length depends on the quantity of air which must be entrained to give complete combustion. A long flame is therefore correlated with a large combustion air requirement whioh in turn is correlated with a large rate of heat release. There are difficulties involved in measuring the flame length because of the turbulent nature of the flame and possible obstruction by smoke. An alternative to measuring the flame length is therefore to measure the rate of heat release [11]. This apparent correlation between the flame length and the rate of heat release is shown for comparable tests in Table 3 and Figure 7 .

The results from the two test series show that sprays from hydraulic fluids can burn when they hit an ignition source, in spite of this they are sometimes classified as fire-resistant in small-scale tests. The combustion efficiency is influenced by a number of properties such as the size- and number distribution of the droplets, and the type of hydraulic fluid etc. Comparable tests in the two test series have shown that the combustion efficlency for hydraulic fluid spray fires differs with the hydraulic fluid used but is relatively independent of hydraulic fluid pressure, nozzle size and spray angle. The same conditions seem to be valid for the radiant fraction and smoke- and toxic gas potential. In Figure 8 the total and radiant heat output per gram sprayed fluid are shown as a function of the fluids net heat of combustion. The net heat of combustion of a hydraulic fluid seems to be the most important parameter which controls the combustion efficiency in spite of differences in the auto-jgnition temperature of a few hundred degrees $C$. 


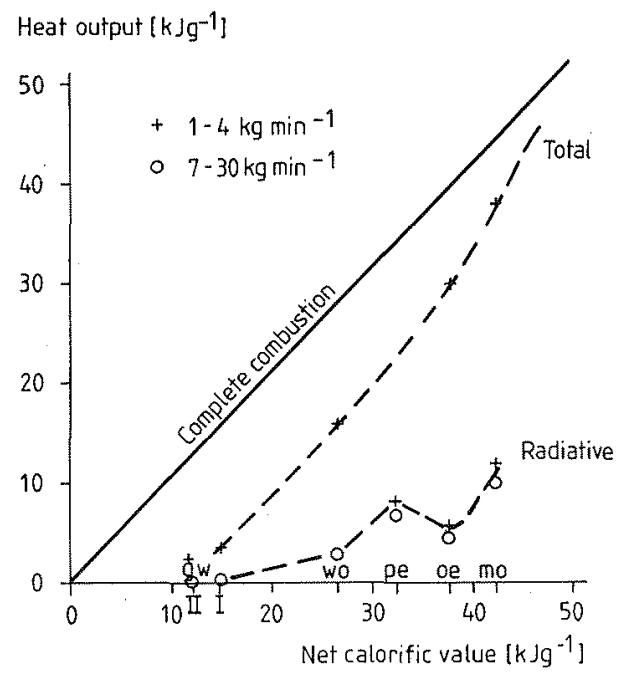

Fig. 8 Total and radiation output from burning hydraulic fluid as a function of the fluids net heat of combustion

The tests showed that a spray fire close to the floor often led to a pool fire and that thin thermocouple wires through the spray led to small fires which stabilized the spray fire. These test series have therefore been performed with the ignition source on during the whole test. Tests which assess the ability of free fluid sprays to stabilize themselves when the ignition source is withdrawn are often dependent on the cholce of spray nozzle. The size of the ignition source does not seem to have a pronounced influence on the combustion efficienoy of the fluids. The combustion efficienoy was hardly affected when fluid flow rates varying from 1 to $30 \mathrm{~kg} \mathrm{~min}^{-1}$ were sprayed against a $200 \mathrm{~kW}$ propane burner as well as when a constant flow of $2 \mathrm{~kg} \mathrm{~min}{ }^{-1}$ mineral oil was sprayed against four different diffusion flames varying from a cigarett lighter to 200 $\mathrm{kW}[21]$.

\section{CONCLUSION}

The results from the two test series show that sprays of hydraulic fluids can burn when they hit an ignition source in spite of the fact that they have been characterized as fire-resistant on the basis. of small scale tests. To assess the fire hazards associated with hydraulic fluids, the testing method should determine the combustion efficiency, net heat of combustion, radiant fraction and smoke- and toxic gas potential of the fluid.

\section{A CKNOWLED GMENT}

This work was supported by the Swedish Fire Researoh Board and National Testing Institute, Sweden. 


\section{REFERENCES}

1. Bäckström, H., Skandia (PM 811216).

2. Romans, J.B. and Little, R.C., Eire Safety Journal 5 (1983), p 115.

3. Test Procedure: Less Hazardous Hydraulic Fluid, Factory Mutual Research, June, 1975 .

4. High Temperature - High Spray Ignition, Eederal Test method Standard 791, Method $6052 \mathrm{~T}$.

5. Low Pressure Spray Ignition, AMS - 3150 C.

6. Loftus, J.J., et al, Flammability Measurements on fourteen different hydraulic fluids using a temperature pressure spray ignition test, NBSIR $81-2247$, U.S. Department of commerce.

7. Loftus, J.J., MSHA Wick test for hydraulic fluids: A preliminary evaluation, NBSIR $81-2312$, U.S. Department of commerce.

8. Loftus, J.J., An evaluation of the MSHA temperature-pressure spray ignition test of hydraulio fluids, NBSIR_81__2 373 , U.S. Department of commerce.

9. Loftus, J.J., An assessment of three different fire resistance tests for hydraulic fluids, NBSIR 81__2395, U.S. Department of commerce.

10. Flammability spray test for hydraulic fluids, Draft for Development 61, British Standard Institution, London (1979).

11. Roberts, A.F. and Brookes, F.R., Fire and Materials 5 (1981), p 87.

12. CETOP RP 77 H 760301, (Comité Européen des Transmissions Gléo Hydrauliques et Pneumatiques).

13. Raback, E. Prov för att iaktta några olika brinnande vätskors spridningsförmaga, Fagersta AB (1979).

14. Wickström, U., Sundström, B. and Holmstedt, G.S., Elre Safety Journal 5 (1983), p 191 .

15. Fuggett, C., Fire and Materials $4(1980)$, p. 61.

16. Parker, W.J., Calculation of the Heat Release Rate for oxysen Consumption for Various Applications, NBSIR 81_-2427-1, U.S. Department of commerce.

17. Rasbash, D.J. and Pratt, B.T., Fire Safety Journal, 2 $(1979 / 80), 23-37$.

18. Holmstedt, G.S., Persson, H. and Rydermann, A., Teknisk Rapport SP-RAPP $1983: 29$ ISSN $0280-2503$.

19. Hilado, C.J. and Clark, S.W., Fire Technology 8 (1972), p 218.

20. Faeth, G.M.; Prog. Energy Combust. Sci. 8 (1977), p 191 .

21. Persion, H., Teknisk Rapport SP-RAPP $1983: 50$ ISSN 0280-2503. 
